\title{
Retraction Note to: Diagnosing breast cancer with an improved artificial immune recognition system
}

\author{
Mahmoud Reza Saybani ${ }^{1,2} \cdot$ Teh Ying Wah ${ }^{1}$. Saeed Reza Aghabozorgi ${ }^{1} \cdot$ \\ Shahaboddin Shamshirband ${ }^{3}$ - Miss Laiha Mat Kiah ${ }^{3}$ - Valentina Emilia Balas ${ }^{4}$
}

Published online: 22 January 2021

(C) Springer-Verlag GmbH Germany, part of Springer Nature 2021

\section{Retraction to: Soft Comput (2016) 20:4069-4084 https://doi.org/10.1007/s00500-015-1742-1}

The Editors have retracted this article [1] because it shows significant overlap with another publication by the same authors [2]. This article is therefore redundant. The corresponding author Mahmoud Reza Saybani stated on behalf of all co-authors that they do not agree to this retraction.

\section{References}

1. Saybani MR, Wah TY, Aghabozorgi SR et al (2016a) Soft Comput 20:4069. https://doi.org/10.1007/s00500-015-1742-1

2. Saybani MR, Shamshirband S, Golzari S et al (2016b) Med Biol Eng Comput 54:385. https://doi.org/10.1007/s11517-015-1323-6

Publisher's Note Springer Nature remains neutral with regard to jurisdictional claims in published maps and institutional affiliations.

The original article can be found online at https:// doi.org/10.1007/s00500-015-1742-1.

\section{Mahmoud Reza Saybani} saybani@gmail.com

Saeed Reza Aghabozorgi shamshirband@um.edu.my

1 Department of Information Systems, Faculty of Computer Science and Information Technology, University of Malaya, 50603 Kula Lumpur, Malaysia

2 Department of Computer Networks, University of Applied Science, Markaz-e Elmi Karbordi Bandar Abbas 1, Bandar Abbas, Iran

3 Department of Computer System and Technology, Faculty of Computer Science and Information Technology, University of Malaya, 50603 Kuala Lumpur, Malaysia

4 Department of Automation and Applied Informatics, Aurel Vlaicu University of Arad, 310130 Arad, Romania 